\title{
PERILAKU PASANGAN YANG BARU MENIKAH DALAM MENUNAIKAN ZAKAT FITRAH
}

\author{
Widi Nopiardo \\ Afrian Raus \\ Institut Agama Islam Negeri (IAIN) Batusangkar \\ e-mail: widinopiardo@rocketmail.com
}

\begin{abstract}
Zakat fitrah is a number of treasures that must be fulfilled by any person, sentient, and baligh, every person who is paid by it in order with certain conditions. The purpose of this research is to know the behavior of newly married couples in district Five Clans in some elements, namely command in addressing behavior Zakah, fitrah zakat fitrah in calculating the behavior that will be fulfilled, behavior in choosing the form of zakat which ended behavior in choosing media distribution of zakat, and behavior in choosing the time of zakat. This type of research is a field research with quantitative analysis approach to qualitative and descriptive. The data collected through questionnaires. The results of this research in the form of percentage of respondents answer appropriate behavior indicators chosen by the respondent. From research conducted there is variation in the answers of the respondents on each indicator behavior with varying percentages.
\end{abstract}

Keywords: Behavior, Zakah, and Newly Married Couples 


\section{Widi Nopiardo dan Afrian Raus}

\section{Pendahuluan}

Dalam al-Quran banyak ditemukan firman Allah yang memerintahkan kita untuk bersedekah dan membelanjakan sebagian harta kita di jalan kebaikan. Namun ironisnya sebagian orang masih ada yang tidak menghiraukan perintah tersebut karena mereka khawatir kalau bersedekah akan mengurangi jumlah hartanya. Sifat kikir dan tamak mendorong orang tersebut untuk enggan membayar zakat, infak, dan sedekah. Padahal manfaat sedekah itu sebenarnya akan kembali kepada diri sendiri.

Allah melipat gandakan pahala sedekah sampai 700 kali lipat, sebagaimana disebutkan dalam al-Quran surat al Baqarah ayat 261 yang artinya: "Perumpamaan (nafkah yang dikeluarkan oleh) orang-orang yang menafkahkan hartanya di jalan Allah adalah serupa dengan sebutir benih yang menumbuhkan tujuh bulir, pada tiaptiap bulir seratus biji. Allah melipat gandakan (ganjaran) bagi siapa yang Dia kehendaki. Dan Allah Maha Luas (karunia-Nya) lagi Maha Mengetahui." (QS. Al-Baqarah: 261).

Banyak keutamaan berinfak di jalan Allah seperti lolos dari berbagai bencana dan musibah dengan bersedekah. Ternyata sedekah dapat menyelamatkan seseorang dari kebangkrutan, tekanan ekonomi, berbagai penyakit dan penderitaan berkepanjangan, dan berbagai keutamaan lainnya.

Tidak patut jika ada anggapan bahwa zakat sebagai pengeluaran yang akan membuat orang jatuh miskin. Zakat adalah salah satu kewajiban dalam Islam, zakat termasuk salah satu dari rukun Islam. Alquran dan sunnah serta ijma' telah menunjukkan kewajibannya, barang siapa mengingkari kewajibannya maka ia termasuk orang-orang zalim yang berhak mendapatkan sanksi dari Allah SWT.

Dalam Islam kewajiban zakat memiliki makna yang sangat fundamental. Selain berkaitan erat dengan aspek ketuhanan, zakat juga erat kaitannya dengan aspek sosial, ekonomi, dan 
kemasyarakatan. Zakat memiliki peran sebagai distribusi dan redistribusi penghasilan dari golongan mampu kepada golongan yang kurang atau tidak mampu dan pada dasarnya merupakan pengembalian sebagian harta kekayaan orang-orang yang mampu untuk menjadi milik orang yang tidak berpunya (Ahmad, 1979: 88). Zakat juga bersinggungan dengan aspek muamalah.

Muamalah merupakan hubungan horizontal terhadap sesama manusia dan hubungan manusia dengan lingkungannya (Kaelany, 2000: 201). Dalam konteks inilah Islam memberikan tekanan pada keseimbangan kehidupan, yakni memandang kehidupan di dunia sama pentingnya dengan kehidupan di akhirat kelak. Selain itu, Islam pun memandang kehidupan dunia sama pentingnya dengan pembangunan kehidupan sosial, mencari nafkah untuk kehidupan dunia sama pentingnya dengan pergi ke masjid untuk beribadah. Islam tidak melarang penganutnya untuk berusaha mencari harta, hanya saja ketika seseorang sudah berhasil mendapatkan harta, maka harus diingat bahwa di dalam harta itu terdapat hak orang lain (Umrotul Khasanah, 2010: 2). Dengan bermuamalah akan memperkuat rasa solidaritas antara sesama manusia, menumbuhkan rasa saling menyayangi serta dapat meningkatkan semangat hidup manusia, khususnya dengan adanya zakat.

Perihal zakat merupakan salah satu rukun Islam dan merupakan kewajiban agama yang dibebankan atas harta kekayaan seseorang menurut aturan tertentu (Mohammad Daud Ali, 1988: 9).

Karena membayar zakat merupakan ibadah wajib untuk umat Islam, maka menghitung berapa besar zakat yang harus dibayar dapat dilakukan sendiri dengan penuh kesadaran iman dan takwa (self assessment). Huda (dalam Gusfahmi, 2011: 61). Jika pendapatan seseorang tersebut melebihi nisab wajib untuk mengeluarkan zakatnya. Tidak selayaknya ada anggapan bahwa zakat sebagai pengeluaran yang akan membuat orang jatuh 
miskin. Dari segi jenisnya zakat terbagi dua yaitu zakat fitrah dan zakat mal.

Zakat fitrah adalah sejumlah harta yang wajib ditunaikan oleh setiap orang Islam, baligh, berakal dan setiap orang yang nafkahnya ditanggung olehnya dengan syarat-syarat tertentu. Diwajibkan menunaikan zakat fitrah sejak matahari tenggelam pada hari akhir bulan Ramadhan atau waktu masuknya malam Idul Fitri (Muhammad, 2002: 25-29).

Sedangkan zakat maal menurut bahasa berasal dari kata tazkiyah yang artinya menyucikan harta benda. Sedang menurut Istilah kadar harta benda tertentu yang wajib dikeluarkan oleh umat Islam yang memenuhi syarat kepada orang yang berhak menerimanya.

Oleh karena itu siapa pun yang wajib mengeluarkan zakat haruslah menunaikan zakat termasuk pasangan yang baru menikah di Kecamatan Lima Kaum. Kecamatan ini cukup padat penduduknya, Kecamatan Lima Kaum terdiri dari 5 nagari yaitu Limo Kaum, Baringin, Cubadak, Labuh, dan Parambahan, memiliki penduduk sebesar 36.626 jiwa dengan luas lebih kurang 5.000 Ha.

Pasangan yang baru menikah cenderung untuk berbuat yang terbaik dan menghindari konflik. Dorongan untuk berbuat baik ini setidaknya juga bersinggungan dengan aspek menunaikan zakat fitrah, dimana kualitas penunaian zakat fitrah akan tergambar dari perilaku pasangan tersebut dalam penunaiannya.

Dalam artikel ini berupaya mengungkapkan perilaku berzakat pasangan yang baru menikah di Kecamatan Lima Kaum yang difokuskan kepada perilaku mereka dalam menunaikan zakat fitrah dimana belum diketahui secara pasti bagaimana perilaku mereka dalam menyikapi perintah menunaikan zakat fitrah, bagaimana mereka menghitung zakatnya, bagaimana perilaku mereka dalam memilih bentuk zakat fitrah yang akan 
ditunaikan, kapan waktu mereka menunaikan zakat fitrah, dan apa media mereka dalam menunaikan zakatnya.

\section{Pembahasan}

\section{Definisi zakat}

Secara etimologis, zakat berasal dari kata dasar bahasa Arab zaka yang berarti berkah, tumbuh, bersih, baik, dan bertambah. Sedangkan secara terminologis di dalam fikih, zakat adalah sebutan atau nama bagi sejumlah harta tertentu yang diwajibkan Allah SWT supaya diserahkan kepada orang-orang yang berhak (mustahiq) oleh orang-orang yang wajib mengeluarkan zakat (muzakki) (Ambary, dkk., 1999: 224).

Ada pendapat beberapa ulama mengenai pengertian zakat (Wahbah az-Zuhayly, 1995: 83-84), yaitu:

Pertama, Menurut mazhab Maliki, definisi zakat adalah "mengeluarkan sebagian yang khusus dari harta yang khusus pula yang telah mencapai nisab (batas kuantitas yang mewajibkan zakat) kepada orang-orang yang berhak menerimanya (mustahiq) nya. Dengan catatan, kepemilikan itu penuh dan mencapai haul (setahun), bukan barang tambang dan bukan pertanian."

Kedua, Menurut mazhab Hanafi, zakat adalah "menjadikan sebagian harta yang khusus dari harta yang khusus sebagai milik orang yang khusus, yang ditentukan oleh syari'at karena Allah SWT."

Ketiga, Menurut mazhab Syafi'i, zakat adalah sebuah ungkapan untuk keluarnya harta atau tubuh sesuai dengan cara khusus.

Keempat, Menurut mazhab Hambali, zakat adalah hak yang wajib (dikeluarkan) dari harta yang khusus untuk kelompok yang khusus pula.

Menurut istilah ekonomi, zakat merupakan tindakan pemindahan kekayaan dari golongan kaya kepada golongan tidak punya (Adiwarman Karim, 2001: 32). Salah satu ajaran penting 


\section{Widi Nopiardo dan Afrian Raus}

yang terdapat dalam agama Islam adalah urgensi zakat kaitannya dengan pengentasan kemiskinan. Sebagai sebuah dinamika keagamaan, zakat merupakan bentuk kesaksian manusia (syahadah al-insan) pada rukun Islam yang keempat di hadapan Allah yang muaranya tertuju pada dimensi kemanusiaan.

\section{Landasan kewajiban zakat}

Zakat telah difardhukan di Madinah pada bulan Syawal tahun kedua hijrah setelah kepada umat Islam diwajibkan berpuasa Ramadhan. Zakat merupakan salah satu rukun Islam yang selalu disejajarkan dengan shalat. Inilah yang menunjukkan betapa pentingnya zakat sebagai salah satu rukun Islam (Abdul Hamid Mahmud, 2006: 1). Banyak ayat alquran dan hadis yang menyinggung persoalan zakat beberapa diantaranya yang berupa dasar-dasar atau landasan kewajiban mengeluarkan zakat disebutkan dalam surat al-Baqarah ayat 43, surat at-Taubah ayat 103, surat al-An'am ayat 141, dan surat at-Taubah ayat 5.

Sedangkan dalil zakat yang berasal dari hadis adalah hadis yang diriwayatkan oleh Bukhari dan Muslim dari Abdullah bin Umar. Rasulullah SAW bersabda: "Telah menceritakan kepada kami (Abdullah bin Musa) dia berkata, telah mengabarkan kepada kami (Hanzhalah bin Abu Sufyan) dari ('Ikrimah bin Khalid) dari (Ibnu Umar) berkata: Rasulullah SAW bersabda: Islam dibangun di atas lima (landasan); persaksian tidak ada Ilah selain Allah dan sesungguhnya Muhammad utusan Allah, mendirikan solat, menunaikan zakat, haji dan puasa Ramadhan." (HR. Bukhari)

Selain itu adalah hadis yang diriwayatkan oleh Ahmad dan Muslim dari Syaiban bin Farrukh: "Telah menceritakan kepada kami (Syaiban bin Farrukh) telah menceritakan kepada kami (Abul Asyhab) telah menceritakan kepada kami (Khulaid Al 'Ashari) dari (Al Ahnafbin Qais) ia berkata; Saya pernah berada dalam sebuah rombongan orangorang Quraisy, lalu (Abu Dzar) lewat sambil mengatakan, "Berilah kabar gembira kepada orang-orang yang menumpuk harta (dan tidak membayar zakatnya), bahwa mereka akan disiksa dengan seterika di 
punggung mereka yang keluar dari lambung dari tengkuk mereka." Setelah itu, ia menyingkir dan duduk. Kemudian saya bertanya: "Siapa ini?" orang-orang pun menjawab, "Ini adalah Abu Dzar." Maka aku pun mendekatinya dan bertanya: "Apa ucapanmu yang baru saja aku dengar tadi?" Abu Dzar menjawab: "Tidaklah aku mengatakan sesuatu tadi, kecuali aku telah mendengarnya dari Nabi SAW." Kemudian aku tanyakan, "Bagaimana pendapatmu tentang pemberian ini?" Abu Dzar menjawab: "Ambillah karena pemberian itu sekarang sebagai pertolongan, namun jika pemberian itu untuk membayar agamamu, maka tinggalkanlah." (HR. Ahmad dan Muslim)

Dan hadis yang diriwayatkan oleh Thabrani dalam alAusath dan as-Shaghir dari Ali: "Allah Ta'ala mewajibkan zakat pada harta orang-orang kaya dari kaum muslimin sejumlah yang dapat melapangi orang-orang miskin di antara mereka. Fakir miskin itu tiadalah akan menderita menghadapi kelaparan dan kesulitan sandang kecuali karena perbuatan golongan kaya, ingatlah Allah akan mengadili mereka nanti secara tegas dan menyiksa mereka dengan pedih." (HR. Thabrani)

\section{Rukun zakat}

Rukun zakat adalah mengeluarkan sebagian dari nisab (harta) yang dengan melepaskan kepemilikan terhadapnya, menjadikannya sebagai milik orang fakir dan menyerahkan kepadanya atau harta tersebut diserahkan kepada wakilnya yakni imam atau orang yang bertugas untuk memungut zakat (Muhammad Abdul Malik Ar-Rahman, 2003: 97).

\section{Syarat Wajib Zakat}

Wahbah az-Zuhayly (Fakhruddin, 2008: 32) membagi syarat wajib zakat menjadi:

a) Merdeka, artinya bukan budak.

b) Beragama Islam.

c) Baligh dan berakal. 
d) Harta yang dikeluarkan adalah harta yang wajib dizakati.

e) Harta yang dimiliki sudah mencapai nisab (batas minimal banyaknya harta yang dimiliki) atau senilai dengannya.

f) Memiliki harta secara sempurna, harta yang dimiliki adalah miliknya sendiri.

g) Kepemilikan harta telah mencapai setahun, menurut hitungan tahun qamariyah.

h) Harta tersebut bukan merupakan harta hasil hutang.

i) Melebihi kebutuhan dasar atau pokok.

j) Harta tersebut harus didapatkan dengan cara yang baik dan halal.

k) Berkembang.

\section{Macam-macam Zakat}

Zakat terbagi atas dua jenis yakni zakat fitrah dan zakat maal (zakat harta). Zakat fitrah adalah sejumlah harta yang wajib ditunaikan oleh setiap orang Islam, baligh, berakal dan setiap orang yang nafkahnya ditanggung olehnya dengan syarat-syarat tertentu. Diwajibkan menunaikan zakat fitrah sejak matahari tenggelam pada hari akhir bulan Ramadhan atau waktu masuknya malam Idul Fitri. Zakat fitrah diwajibkan disesuaikan dengan makanan pokok penduduk suatu daerah, baik berupa gandum, kurma, susu, keju, beras. (Muhammad, 2002: 25-29).

Zakat fitrah merupakan zakat yang wajib dikeluarkan muslim menjelang Idul Fitri pada bulan Ramadhan. Besar zakat ini setara dengan 2,5 kilogram/ 3,5 liter makanan pokok yang ada di daerah bersangkutan. Syarat wajib zakat fitrah ada tiga, yaitu: Islam, memiliki bahan makanan lebih dari satu sha' untuk kebutuhan dirinya dan keluarganya selama sehari semalam ketika hari raya, dan telah masuk waktu wajibnya pembayaran zakat, yaitu ketika terbenamnya matahari di hari puasa terakhir, menjelang tanggal satu Syawal. 
Zakat mal mencakup hasil perniagaan, pertanian, pertambangan, hasil laut, hasil ternak, harta temuan, emas dan perak. Masing-masing tipe memiliki perhitungannya sendirisendiri. Di dalam kitab-kitab hukum Islam (fiqh) harta kekayaan yang wajib dizakati digolongkan ke dalam kategori (Ridwan Mas'ud dan Muhammad, 2005: 45): Emas, perak, dan uang (simpanan) (QS. at-Taubah: 34-35); Barang yang diperdagangkan (QS. al-Baqarah: 267); Hasil peternakan (QS. al-Baqarah: 267); Hasil bumi (QS. al-Baqarah: 267); Hasil tambang dan barang temuan (QS. al-Baqarah: 267).

\section{Perilaku muzakki di Indonesia dalam membayarkan zakat}

Perilaku pembayar zakat adalah cara muzakki dalam melakukan kewajiban atas harta zakat yang ada pada dirinya guna menunaikan kewajiban sebagai seorang muslim.

Berikut disebutkan beberapa perilaku muzakki di Indonesia dalam membayarkan zakatnya yang didasarkan pada indikator berikut ini (Uzaifah, 2007: 129-130);

1. Cara menghitung zakat, yaitu zakat harta (uang, emas, dan perak) dibayarkan 2,5\% setelah mencapai nisab atau 2,5\% setelah sempurna dimiliki selama satu tahun berapapun banyaknya jumlah harta. Zakat pencarian dan profesi dibayarkan 2,5\% pendapatan bersih atau 2,5\% pendapatan kotor. Zakat kekayaan dagang dibayarkan 2,5 $\%$ keuntungan atau 2,5\% modal.

2. Bentuk dari zakat yang disalurkan bisa berupa barang dan bisa juga berupa uang.

3. Media penyaluran zakat bisa melalui masjid, yayasan sosial, alim ulama, melalui amil zakat, atau langsung disalurkan secara individu.

4. Waktu pembayaran zakat, yaitu zakat harta (uang, emas, dan perak) dan zakat kekayaan dagang dibayarkan setahun sekali sekitar bulan Ramadhan atau setahun sekali di luar bulan Ramadhan. untuk zakat pencarian 
dan profesi dibayarkan setiap mendapat hasil profesi atau setahun sekali.

5. Jalur pembayaran zakat bisa melalui institusi tempat muzakki bekerja ataupun tidak melalui institusi tempat muzakki bekerja.

Untuk cara perhitungan harta zakat untuk zakat harta tidak ada perdebatan pada keempat mazhab karena perhitungan zakat harta adalah jelas setelah mencapai nisab dan sempurna dimiliki selama satu tahun. Untuk zakat pencarian dan profesi perhitungannya tergantung dari apakah harta pencarian dan profesi adalah sebagai modal saja ataukah modal yang dikembangkan. Untuk zakat kekayaan dagang keempat mazhab sepakat bahwa zakat kekayaan dagang diambil dari jumlah seluruh kekayaan dagangan yang dinominalkan dengan uang yang sudah mencapai nisab di akhir tahun. Zakat dapat disalurkan dalam bentuk barang maupun uang, keempat mazhab sepakat bahwa lebih utama zakat dikeluarkan dalam bentuk uang. Pembayaran zakat diperbolehkan untuk melakukannya baik setiap mendapatkan penghasilan maupun setelah satu tahun baru dihitung jumlah zakat yang harus dikeluarkan. Tidak ada perbedaan pendapat dari para ulama mazhab besar dalam pembayaran zakat apakah melalui sistem potong gaji menurut aturan perusahaan atau institusi maupun tidak dipotong gaji oleh perusahaan maupun institusi. Mengenai media penyaluran zakat akan lebih diperinci pendapat-pendapat yang dikemukakan oleh keempat mazhab.

\section{Metode penelitian}

Jenis penelitian ini adalah field research, yakni semua data penelitian didapatkan di lapangan, dengan pendekatan analisis kuantitatif dan deskriptif kualitatif. Populasi dalam penelitian ini adalah semua pasangan yang umur pernikahannya $\leq 1$ tahun atau tepatnya 8 bulan dari Januari s.d. Agustus 2016. Sampel adalah sebagian atau wakil populasi yang diteliti (Sugiyono, 2010: 118). 
Sedangkan Maman dan Sambas menerjemahkan populasi sebagai "bagian kecil dari anggota populasi yang diambil menurut prosedur tertentu sehingga dapat mewakili populasi" (Maman Abdurrahman dan Sambas Ali Muhidin, 2011: 119).

Dalam penelitian ini jumlah populasi pasangan yang baru menikah rentang 02 Januari s.d 08 Agustus 2016 adalah sebanyak 190 pasangan (Buku Pencatatan Peristiwa Nikah Kecamatan Lima Kaum Tahun 2016 M/ 1437 H).

Margono mengutip dari Sudjana mengatakan bahwa “alasan-alasan penelitian dilakukan dengan mempergunakan sampel adalah (S. Margono, 2005: 121-122); ukuran populasi, masalah biaya, masalah waktu, percobaan yang sifatnya merusak, masalah ketelitian, dan masalah ekonomis

Menurut Sugiyono (2003: 62), dalam menentukan besarnya sampel yaitu menggunakan tabel Krejcie. Krejcie dalam melakukan perhitungan ukuran sampel didasarkan atas kesalahan 5\%. Jadi sampel yang diperoleh itu mempunyai kepercayaan 95\% terhadap populasi. Maka pengambilan jumlah sampel mengacu berdasarkan pada tabel Krejcie, yaitu dengan jumlah populasi antara 190 maka sampel yang digunakan sebanyak 127 . Sehingga dalam penelitian ini dengan jumlah populasi sebanyak 190 pasangan,maka sampel yang akan diambil sebanyak 127 pasangan.

Instrumen yang utama adalah peneliti sendiri. Untuk mengumpulkan data, peneliti akan menggunakan lembaran angket. Lembaran angket tersebut akan digunakan untuk mendata berbagai keadaan/ kondisi yang dimunculkan selama penelitian dengan indikator yang telah ditetapkan.

Jenis data yang dikumpulkan berupa data kuantitatif (untuk mengetahui persentase) indikator yang ditanya dan kualitatif (pendeskripsian data tentang perilaku yang diperoleh di lapangan). Sumber data penelitian yaitu dari kuesioner yang diperoleh secara langsung dari sumber asli atau responden. Di samping itu juga memanfaatkan data-data yang sudah 
tersedia pada instansi berupa buku-buku dan sumber yang relevan lainnya.

Untuk mengumpulkan data digunakan beberapa teknik yaitu: pertama, kuesioner, merupakan teknik pengumpulan data yang dilakukan dengan cara memberi seperangkat pertanyaan tertulis kepada responden untuk dijawabnya (Achmad, 2010: 199). Dalam penelitian ini daftar pernyataan atau kuesioner akan peneliti gunakan untuk memperoleh informasi tentang perilaku pasangan baru menikah dalam membayar zakat fitrah. Jenis kuesioner dalam penelitian ini bersifat semi tertutup dengan metode pernyataan yang terarah, peneliti menyediakan pernyataan (indikator perilaku), responden diminta untuk memilih pernyataan yang dituangkan dalam kuesioner sesuai realita perilaku berzakat responden dengan mencentang atau memberi tanda check list. Pernyataan disusun berdasarkan batasan masalah. Kedua, studi pustaka, digunakan dalam keseluruhan proses penelitian dengan memanfaatkan berbagai macam pustaka yang relevan dengan masalah yang sedang diteliti.

Data akan dianalisis menggunakan analisis deskriptif dengan menampilkan hasil dalam persentase jawaban responden dari indikator yang diteliti dan mendeskripsikannya.

Statistik deskriptif untuk mendeskripsikan bagaimana tingkat kesadaran masyarakat dalam membayar zakat penulis menggunakan statistik deskriptif, yaitu metode statistik yang berusaha menjelaskan atau menggambarkan berbagai karakteristik data seperti berapa rata-ratanya, seberapa jauh datadata bervariasi, dan lain sebagainya (Muhamad, 2008: 200).

\section{Pembahasan}

\section{Perilaku dalam menyikapi perintah menunaikan zakat fitrah}

Berdasarkan pernyataan perilaku dalam menyikapi perintah menunaikan zakat fitrah diperoleh hasil sebagai berikut: 
Perilaku Pasangan yang Baru Menikah dalam Menunaikan Zakat fitrah

Tabel 1.

Data Perilaku dalam Menyikapi Perintah Menunaikan Zakat Fitrah

\begin{tabular}{clcc}
\hline No & \multicolumn{1}{c}{ Indikator } & Persentase & Jumlah \\
\hline 1 & $\begin{array}{l}\text { Kesadaran untuk menunaikan } \\
\text { zakat fitrah muncul dari diri } \\
\text { sendiri sebelum menikah }\end{array}$ & $100 \%$ & 127 orang \\
\hline 2 & $\begin{array}{l}\text { Kesadaran untuk menunaikan } \\
\text { zakat fitrah muncul dari motivasi } \\
\text { pasangan setelah menikah }\end{array}$ & $0 \%$ & 0 orang \\
\hline 3 & $\begin{array}{l}\text { Kesadaran untuk menunaikan } \\
\text { zakat fitrah muncul dari motivasi } \\
\text { orang lain }\end{array}$ & $0 \%$ & 0 orang \\
\hline \multicolumn{1}{c}{ Total } & $100 \%$ & 127 orang \\
\hline
\end{tabular}

Sumber: Data diolah dari kuesioner

Dari tabel di atas dapat dideskripsikan bahwa sebanyak 100 $\%$ atau 127 orang dari responden menjawab bahwa kesadarannya untuk menunaikan zakat fitrah muncul dari diri sendiri sebelum menikah. Sebanyak $0 \%$ atau 0 orang dari responden menjawab bahwa kesadarannya untuk menunaikan zakat fitrah muncul dari motivasi pasangan setelah menikah. Sebanyak $0 \%$ atau 0 orang dari responden menjawab bahwa kesadarannya untuk menunaikan zakat fitrah muncul dari motivasi orang lain.

\section{Perilaku dalam menghitung zakat fitrah}

Berdasarkan pernyataan perilaku dalam menghitung zakat fitrah yang akan ditunaikan diperoleh hasil sebagai berikut:

Tabel 2

Data Perilaku dalam Menghitung Zakat Fitrah

\begin{tabular}{|c|c|c|c|}
\hline No & Indikator & Persentase & Jumlah \\
\hline 1 & $\begin{array}{l}\text { Menunaikan zakat fitrah dengan } \\
\text { cara menghitung sendiri zakat } \\
\text { fitrah yang akan ditunaikan } \\
\text { dengan perhitungan satu sho' } \\
\text { atau kurang lebih } 2,5 \mathrm{~kg} \text { atau } 3 \\
1 / 3 \text { liter dikali harga beras yang } \\
\text { dikonsumsi. }\end{array}$ & $2,36 \%$ & 3 orang \\
\hline
\end{tabular}


Menunaikan zakat fitrah sesuai

2 ketentuan yang ditetapkan oleh pengurus masjid/ mushalla di $97,64 \% \quad 124$ orang sekitar tempat tinggalnya.

\begin{tabular}{ccc}
\hline Total & $100 \%$ & 127 orang \\
\hline
\end{tabular}

Sumber: Data diolah dari kuesioner

Dari tabel di atas diperoleh informasi bahwa sebanyak 2,36 $\%$ atau 3 orang dari responden menghitung sendiri zakat fitrah yang akan ditunaikan dengan perhitungan satu sho' atau kurang lebih 2,5 $\mathrm{kg}$ atau 3 1/3 liter dikali harga beras yang dikonsumsi. Sedangkan sebanyak 97,64\% atau 124 orang menghitung zakat fitrah yang akan ditunaikan melalui bantuan pengurus masjid/ mushalla di sekitar tempat tinggalnya.

Ini membuktikan bahwa pengumuman dari pengurus masjid/ mushalla tentang besaran zakat fitrah yang akan ditunaikan secara tidak langsung membentuk perilaku pasangan yang baru menikah dalam hal menghitung zakat fitrah yang akan ditunaikan. Sebanyak 97,64 \% menunaikan zakat fitrah sesuai ketentuan yang ditetapkan oleh pengurus masjid/ mushalla di sekitar tempat tinggalnya.

\section{Perilaku dalam memilih bentuk zakat fitrah yang ditunaikan}

Berdasarkan pernyataan perilaku dalam memilih bentuk zakat fitrah yang ditunaikan diperoleh hasil sebagai berikut:

Tabel 3.

Data Perilaku dalam Memilih Bentuk Zakat Fitrah yang Ditunaikan

\begin{tabular}{clrc}
\hline No & \multicolumn{1}{c}{ Indikator } & Persentase & Jumlah \\
\hline 1 & $\begin{array}{l}\text { Menunaikan zakat fitrah berupa } \\
\text { uang. }\end{array}$ & $90,55 \%$ & 115 orang \\
\hline 2 & $\begin{array}{l}\text { Menunaikan zakat fitrah berupa } \\
\text { barang. }\end{array}$ & $9,45 \%$ & 12 orang \\
\hline \multicolumn{2}{c}{ Total } & $100 \%$ & 127 orang \\
\hline
\end{tabular}

Sumber: Data diolah dari kuesioner 
Dari tabel di atas dapat dijelaskan bahwa sebanyak 90,55 $\%$ atau 115 orang dari responden mengeluarkan zakat fitrah berupa uang. Sebanyak 9,45\% atau 12 orang dari responden mengeluarkan zakat fitrah berupa barang.

\section{Perilaku dalam memilih media penyaluran zakat fitrah}

Berdasarkan pernyataan perilaku dalam memilih media penyaluran zakat fitrah diperoleh hasil sebagai berikut:

Tabel 4

Data Perilaku dalam Memilih Media Penyaluran Zakat Fitrah

\begin{tabular}{|c|c|c|c|}
\hline No & Indikator & Persentase & Jumlah \\
\hline 1 & $\begin{array}{l}\text { Menyalurkan zakat fitrah melalui } \\
\text { BAZNAS Tanah Datar karena } \\
\text { responden pandang lebih } \text { afdhal. }\end{array}$ & $0 \%$ & 0 orang \\
\hline 2 & $\begin{array}{l}\text { Menyalurkan zakat fitrah melalui } \\
\text { BAZNAS Tanah Datar karena } \\
\text { terpaksa oleh pimpinan. }\end{array}$ & $0 \%$ & 0 orang \\
\hline 3 & $\begin{array}{l}\text { Menyalurkan zakat fitrah melalui } \\
\text { BAZNAS Tanah Datar karena } \\
\text { dimotivasi oleh pasangannya. }\end{array}$ & $0 \%$ & 0 orang \\
\hline 4 & $\begin{array}{l}\text { Menyalurkan zakat fitrah melalui } \\
\text { Panitia Zakat Fitrah di masjid atau } \\
\text { mushalla di sekitar tempat tinggal } \\
\text { karena responden pandang lebih } \\
\text { afdhal. }\end{array}$ & $72,44 \%$ & 92 orang \\
\hline 5 & $\begin{array}{l}\text { Menyalurkan zakat fitrah melalui } \\
\text { Panitia Zakat Fitrah di masjid atau } \\
\text { mushalla di sekitar tempat tinggal } \\
\text { karena terpaksa oleh orang lain. }\end{array}$ & $0 \%$ & 0 orang \\
\hline 6 & $\begin{array}{l}\text { Menyalurkan zakat fitrah melalui } \\
\text { Panitia Zakat Fitrah di masjid } \\
\text { atau mushalla di sekitar tempat } \\
\text { tinggal karena dimotivasi oleh } \\
\text { pasangannya. }\end{array}$ & $3,94 \%$ & 5 orang \\
\hline 7 & $\begin{array}{l}\text { Menyalurkan zakat fitrah langsung } \\
\text { diserahkan ke mustahik (orang yang } \\
\text { berhak menerima zakat) karena } \\
\text { menurut responden lebih afdhal. }\end{array}$ & $21,26 \%$ & 27 orang \\
\hline
\end{tabular}




\begin{tabular}{|c|c|c|c|}
\hline 8 & $\begin{array}{l}\text { Menyalurkan zakat fitrah langsung } \\
\text { diserahkan ke mustahik (orang yang } \\
\text { berhak menerima zakat) karena } \\
\text { terpaksa oleh desakan orang lain. }\end{array}$ & $0 \%$ & 0 orang \\
\hline \multirow[t]{2}{*}{9} & $\begin{array}{l}\text { Menyalurkan zakat fitrah langsung } \\
\text { diserahkan ke mustahik (orang yang } \\
\text { berhak menerima zakat) karena } \\
\text { dimotivasi oleh pasangannya. }\end{array}$ & $2,36 \%$ & 3 orang \\
\hline & Total & $100 \%$ & $\begin{array}{r}127 \\
\text { orang }\end{array}$ \\
\hline
\end{tabular}

Sumber: Data diolah dari kuesioner

Dari tabel di atas diperoleh data yaitu sebanyak $0 \%$ atau 0 orang dari responden menyalurkan zakat fitrah melalui BAZNAS Tanah Datar karena responden pandang lebih afdhal. Sebanyak $0 \%$ atau tidak ada (0 orang) responden yang menyalurkan zakat fitrah melalui BAZNAS Tanah Datar karena terpaksa oleh pimpinan. Sebanyak $0 \%$ atau 0 orang dari responden menyalurkan zakat fitrah melalui BAZNAS Tanah Datar karena dimotivasi oleh pasangannya. Dalam hal penunaian zakat fitrah tidak ada responden yang menyalurkan zakatnya melalui BAZNAS Tanah Datar.

Penelitian juga menunjukkan bahwa sebanyak 72,44 \% atau 92 orang dari responden menyalurkan zakat fitrah melalui Panitia Zakat Fitrah di masjid atau mushalla di sekitar tempat tinggal karena responden pandang lebih afdhal. Sebanyak $0 \%$ atau tidak ada (0 orang) responden yang menyalurkan zakat fitrah melalui Panitia Zakat Fitrah di masjid atau mushalla di sekitar tempat tinggal karena terpaksa oleh orang lain. Dari penelitian juga diperoleh data sebanyak 3,94\% atau 5 orang dari responden menyalurkan zakat fitrah melalui Panitia Zakat Fitrah di masjid atau mushalla di sekitar tempat tinggal karena dimotivasi oleh pasangannya.

Selanjutnya penelitian mengungkapkan bahwa sebanyak $21,26 \%$ atau 27 orang dari responden menyalurkan zakat fitrah langsung diserahkan ke mustahik (orang yang berhak menerima zakat) karena menurut responden lebih afdhal. Sebanyak $0 \%$ atau 
tidak ada (0 orang) responden yang menyalurkan zakat fitrah langsung diserahkan ke mustahik (orang yang berhak menerima zakat) karena terpaksa oleh desakan orang lain. Sebanyak 2,36 \% atau 3 orang dari responden menyalurkan zakat fitrah langsung diserahkan ke mustahik (orang yang berhak menerima zakat) karena dimotivasi oleh pasangannya.

\section{Perilaku dalam memilih waktu penunaian zakat fitrah}

Berdasarkan pernyataan perilaku dalam memilih waktu penunaian zakat fitrah diperoleh hasil sebagai berikut:

Tabel 5

Data Perilaku dalam Memilih Waktu Penunaian

Zakat Fitrah

\begin{tabular}{clrc}
\hline No & \multicolumn{1}{c}{ Indikator } & Persentase & Jumlah \\
\hline 1 & $\begin{array}{l}\text { Awal bulan Ramadhan (sepuluh } \\
\text { hari pertama) }\end{array}$ & 0 orang \\
\hline 2 & $\begin{array}{l}\text { Pertengahan bulan Ramadhan } \\
\text { (sepuluh hari kedua) }\end{array}$ & $4,72 \%$ & 6 orang \\
\hline 3 & $\begin{array}{l}\text { Akhir Ramadhan (hari ke-21 } \\
\text { sampai menjelang terbenamnya } \\
\text { matahari di akhir Ramadhan) }\end{array}$ & $84,25 \%$ & 107 orang \\
\hline 4 & $\begin{array}{l}\text { Mulai terbenamnya matahari di } \\
\text { akhir Ramadhan sampai menjelang } \\
\text { shalat subuh atau malam takbiran. }\end{array}$ & $11,02 \%$ & 14 orang \\
\hline 5 & $\begin{array}{l}\text { Sesudah sholat subuh sebelum } \\
\text { sholat Idul Fitri. }\end{array}$ & $0 \%$ & 0 orang \\
\hline 6 & $\begin{array}{l}\text { Sesudah sholat Idul Fitri tetapi } \\
\text { sebelum terbenam matahari pada } \\
\text { hari raya Idul Fitri. }\end{array}$ & $0 \%$ & 0 orang \\
\hline 7 & $\begin{array}{l}\text { Sesudah terbenam matahari pada } \\
\text { hari raya Idul Fitri. }\end{array}$ & $0 \%$ & 0 orang \\
\hline & Total \\
\hline
\end{tabular}

Sumber: Data diolah dari kuesioner 
Berdasarkan tabel di atas diperoleh informasi bahwa sebanyak $0 \%$ atau tidak ada (0 orang) dari responden menunaikan zakat fitrah pada awal bulan Ramadhan (sepuluh hari pertama). Sebanyak $4,72 \%$ atau 6 orang menunaikan zakat fitrah pada pertengahan bulan Ramadhan (sepuluh hari kedua). Sebanyak $84,25 \%$ atau 107 orang menunaikan zakat fitrah pada akhir Ramadhan (hari ke-21 sampai menjelang terbenamnya matahari di akhir Ramadhan). Sebanyak $11,02 \%$ atau 14 orang menunaikan zakat fitrah pada saat mulai terbenamnya matahari di akhir Ramadhan sampai menjelang shalat subuh atau malam takbiran. Sebanyak $0 \%$ atau tidak ada (0 orang) menunaikan zakat fitrah pada waktu sesudah sholat subuh sebelum sholat Idul Fitri. Responden sangat hati-hati dalam masalah waktu penunaian zakat fitrah sehingga responden tidak ingin menunaikan zakat fitrah di luar waktu yang telah ditentukan dengan konsekuensi hanya dianggap sebagai sedekah biasa. Hal ini terbukti bahwa sebanyak $0 \%$ atau tidak ada (0 orang) menunaikan zakat fitrah sesudah sholat Idul Fitri tetapi sebelum terbenam matahari pada hari raya Idul Fitri. Sebanyak $0 \%$ atau tidak ada (0 orang) menunaikan zakat fitrah pada waktu sesudah terbenam matahari pada hari raya Idul Fitri.

Berdasarkan data tersebut mengindikasikan bahwa tingkat kedisiplinan berzakat fitrah pasangan baru menikah berada pada tingkat yang cukup tinggi dan terhindar dari menunaikan zakat fitrah tetapi hanya dianggap sebagai sedekah biasa karena sudah lewat batas waktunya.

\section{Simpulan}

Berdasarkan penelitian yang telah dilakukan maka diperoleh kesimpulan bahwa, pertama masing-masing pasangan yang baru menikah mempunyai perilaku yang berbeda dalam hal penunaian zakat. Perbedaan tergambar dari indikator yang dijadikan dasar analisis seperti perilaku dalam menyikapi perintah menunaikan zakat fitrah, perilaku dalam menghitung 
zakat fitrah yang akan ditunaikan, perilaku dalam memilih bentuk zakat fitrah yang disalurkan, perilaku dalam memilih media penyaluran zakat fitrah, dan perilaku dalam memilih waktu pembayaran zakat fitrah. Persentase yang tinggi dari sebuah indikator mengindikasikan kecenderungan perilaku pasangan baru menikah dalam menunaikan zakat fitrah.

\section{Daftar Pustaka}

Abdul Hamid Mahmud, Ekonomi Zakat. RajaGrafindo Persada, Jakarta, 2006.

Adiwarman A. Karim, Ekonomi Islam Suatu Kajian Kontemporer, Gema Insani. Jakarta, 2001.

BAZNAS, Zakat dan Distribusi Ekonomi. http://pusat.baznas. go.id/ diakses pada 1 September 2016.

Buku Pencatatan Peristiwa Nikah Kecamatan Lima Kaum Tahun $2016 \mathrm{M} / 1437 \mathrm{H}$

Fakhruddin, Fiqih dan Manajemen Zakat di Indonesia, UIN-Malang Press, Malang, 2008.

Gusfahmi, Pajak Menurut Syariah, Edisi Revisi II, Rajawali Pers, Jakarta, 2011.

Hasan Muarif Ambary, dkk. Ensiklopedi Islam, PT Ichtiar Baru Van Hueve, Jakarta, 1999.

Kaelany, Islam, Iman, dan Amal Saleh, PT. Rineka Cipta, Jakarta, 2000.

Mamluatul Maghfiroh, Zakat, PT. Pustaka Insan Madani, Yogyakarta, 2007.

Mohammad Daud Ali, Sistem Ekonomi Islam Zakat dan Wakaf, UIPress Jakarta, 1988.

Muhammad Abduh Tuasikal, Panduan Zakat (8): Zakat Hasil Pertanian, (Online), http://muslim.or.id/fiqh-danmuamalah/panduan-zakat-8-zakat-hasil-pertanian.html, diakses pada 28 Juni 2012 


\section{Widi Nopiardo dan Afrian Raus}

Muhammad Abdul Malik Ar Rahman. 1001 Masalah Dan Solusinya, Pustaka Cerdas Zakat, Jakarta, 2003.

Muhammad. Zakat Profesi: Wacana Pemikiran Zakat Dalam Fiqih Kontemporer. Salemba Diniyah, Jakarta, 2002.

Mustafa Edwin Nasution, dkk. Pengenalan Eksklusif Ekonomi Islam, Kencana, Jakarta, 2006.

Ridwan Mas'ud, dan Muhammad, Zakat dan Kemiskinan: Instrumen Pemberdayaan Ekonomi Umat, UII Press, Yogyakarta, 2005.

Umrotul Khasanah, Manajemen Zakat Modern, UIN Maliki Press, Malang, 2010.

Uzaifah, Studi Deskriptif Perilaku Dosen Perguruan Tinggi Islam DIY Dalam Membayar Zakat (online), Jurnal La Riba, Vol. I, No. 1, Juli 2007.

Wahbah Al-Zuhayly, Zakat Kajian Berbagai Mazhab, diterjemahkan oleh Agus Efendi dan Bahruddin Fannany, PT. Remaja Rosdakarya, Bandung, 1995.

Zainal Abidin Ahmad, Dasar-dasar Ekonomi Islam, Cetakan IV, Bulan Bintang, Jakarta, 1979. 